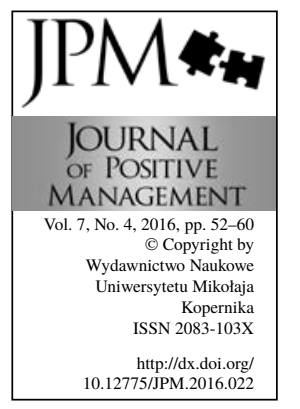

\title{
UNDERSTANDING SUSTAINABLE BUSINESS MODELS
}

\author{
Agata Rudnicka \\ University of Lodz \\ Faculty of Management, Lodz, Poland \\ e-mail:rudnicka@uni.lodz.pl
}

\begin{abstract}
Purpose: Business organizations present different approaches to the implementation of the sustainable development concept to their business models. The scale and scope of implementation of the idea may be related to the level of understanding and prioritizing the issue of sustainability in business operations. The main aim of the paper is presentation of the theoretical background of sustainable business models. Frameworks and borders of the sustainability in management will be proposed.

Approach: There are different aspects taken into consideration when analyzing the idea of business models based on sustainability from environmental responsibility to strategic orientation. Author of the paper will analyze the current literature and based on this improve main elements that describe the theoretical approach to business models including sustainability.

Implications: The paper presents conceptual assumption of sustainable business model. It is the first step to further research. The limits and challenges of sustainable business models are presented. The proposed criteria are used to assess the possibilities of developing and designing sustainable approach of business models in companies.
\end{abstract}

Keywords: corporate sustainability, sustainable business models, criteria of sustainability in business

Paper type: Conceptual paper

\section{Introduction}

There are many different managerial concepts that take into consideration the sustainability issues. They focus on different aspects like the whole economic systems (Chouinard et al., 2011) supply chains of companies (Seuring and Muller, 2008; Ross et al., 2012; Linton et al., 2007) business strategy and processes (Gauthier, 2017; Nidumolu et al., 2009; Lubin and Etsy, 2010; Azzone and Bertele, 1994). The presented paper will focus on the idea of sustainability from the business model perspective. There are terms in literature which describe the issue of sustainable development related to the companies like e.g.: corporate 
sustainability and sustainable corporate entrepreneurship. Business case for sustainability is "the initiation of business practices that lead to long-term environmental, social and economic benefits [...]. It make business to pursue and exploit opportunities that create shared value - value for both the business

UNDERSTANDING SUSTAINABLE BUSINESS MODELS

Agata Rudnicka and for society" (Atiq and Karatas-Ozkan, 2013). Corporate Sustainability can be understood as strategic and profit oriented business reaction to social and environmental issues caused by direct and indirect business operations (Salzmann et al., 2005). It containsthe activities of companies that actively contribute to the balance in the economic, social and environmental aspects and dimensions (past, present and future), taking into account the system of the company and its stakeholders (Lozano, 2012). Moreover "true corporate sustainability requires an integration of all three sustainability dimensions into business management, which can even lead to business model transformations to secure sustainable operations in the long-term" (Lüdeke-Freund, 2009; Weber, 2008). Research literature underlines the role of corporate sustainability as a business case (Asif et al., 2011). There is also a similar term: sustainable corporate entrepreneurship. It could be defined as: "the process of leveraging innovation of an organization's products, processes, strategies, domain, or business models to discover, assess and ultimately exploit attractive economic opportunities created by latent and manifest environmental problems and/or social responsibility issues" (Miles et al., 2009). Other definitions of the term are also proposed (Cohen and Winn, 2007; Dean and McMullen, 2007; Pacheco et al., 2010) but they are all very similar and underline the key elements of sustainable business approach like: social and environmental context of business strategy, integration of TBL approach and business strategy, profit oriented approach, stakeholders involvement and long term planning.

In practice the level of engagement in sustainability issues may be different when comparing organizations from different industries, sizes, locations etc. The peripheral engagement is mostly related to the issue of image and reputation. In this approach organization focus rather on reactive approach to social and environmental issues. On the other hand one can find organizations that manage their sustainability issues consciously. But the level of concept adaptation and integration with business model can be also differentiated. Generally they are aware of social and environmental challenges and problems and make effort to solve them by incorporating these aspects to business management system. However the scale and scope of actions and investments taken up by companies show rather complex picture of understanding for sustainability on the corporate level. The most mature approach seems to be the incorporation of sustainability into business model and transformation in the direction of sustainable business models. Business research and practice show that it is still not clear and requires a deeper analysis. 
UNDERSTANDING SUSTAINABLE BUSINESS MODELS

Agata Rudnicka
Business models for the purpose of the paper will be understood as: "a conceptual tool that contains a set of elements and their relationships and allows expressing a company's logic of earning money. It is a description of the value a company offers to one or several segments of customers and the architecture of the firm and its network of partners for creating, marketing and delivering this value and relationship capital, in order to generate profitable and sustainable revenue streams" (Osterwalder, 2004). It is set of elements like e.g: value proposition of the product, customer segmentation, distribution channels, relations, value configuration, competences needed to execute the business model, networks of business partners, cost structure and revenue model (Osterwalder et al., 2005) that constitute the main meaning of business and way of earning money. Business model answer the most essential questions about the structure of clients and provided values (Magretta, 2002).

The aim of the article is to define the essence of a sustainable business model. The author attempts to determine the minimum criteria, which seem to be necessary for the proper interpretation of the meaning of sustainability in the context of business model.

\section{Sustainability and Business Models}

Sustainable business model (SBM) can be treated as more mature approach to sustainable business practices than strategy. It is assumed that changes that are made to implement sustainability issues at strategic level and in processes result in reshaping the business model frameworks. Taking into consideration the most recognized approach to sustainability (Triple Bottom Line) (Elkington, 1997), definition of sustainable business models is proposed. "SBM incorporate a triple bottom line approach and consider a wide range of stakeholder interests, including environment and society. They are important in driving and implementing corporate innovation for sustainability, can help embed sustainability into business purpose and processes, and serve as a key driver of competitive advantage" (Bocken et al., 2014). In sustainable business model firm needs to "allocate resources and coordinates activities in a value creation process which overcomes the public/private benefit discrepancy". It requires: integration of public and private benefits, making customers more engaged in the value creation process, setting the good measures that will show environmental and social effects and improving non-market pillar (Luedeke-Freund, 2009). Other propositions highlights the issue of "creating competitive advantage through superior customer value and contributes to a sustainable development of the company and society" (Luedeke-Freund, 2010). Jonker assumes that SBM need to cover four elements: sharing knowledge, making connections (sustainability is between companies), awareness and multiple value creation (Jonker, 2012). Next to the SBM definitions there are also different types of models and concepts developed (Jonker, 2012; 
Model Behavior, Bocken et al., 2014; Stubbs and Coclin, 2008; Epstein and Buhovac, 2010).

Although definitions of SBM show the entire spectrum of critical elements and the essence of sustainability in different dimensions exemplary models reveal

UNDERSTANDING SUSTAINABLE BUSINESS MODELS

Agata Rudnicka some discrepancies when talking about implementation phase. Theoretical models suggest that company may develop only one aspect of sustainability. Such selective perception can lead to misunderstandings and wrong processes of designing and prioritizing sustainable goals. It seems to be obvious that companies should focus and improve this sphere, which is the most problematic or brings the greatest benefit, however, it should be emphasized that in the case of sustainability there are different things that needed to be analyzed at the same time. In practice this is a very complex and demanding process. On the way to a sustainable business model a different modes of business models can be distinguished:

- economic orientation/profit maximization,

- mixed model with social orientation (e.g. social enterprises),

- socially responsible/socially engaged model (with strong orientation on stakeholders management),

- a business model including sustainability (with strategy on corporate level),

- sustainable business model.

Essential question about business models and sustainability is still open. Where are the minimum requirements that organization needs to follow to may call its approach of making business sustainable?

\section{Conceptual framework of sustainability based business models}

Sustainable business model means that the company is open for changes covering culture, structure, business processes and offered products and services. Organizations that are present on the market for many years and have established competitive position require time and resources to re-evaluate their certain goals. Young organizations have easier task to do if sustainability issues are planned and implemented from the beginning.

Taking into consideration the previous discussion it seems to be advisable to establish criteria that need to be taken into consideration when making strategic decisions about sustainability. There are 4 criteria proposed:

- criterion of time,

- criterion of life - cycle,

- criterion of cost-benefit,

- criterion of change.

The first criterion relates to the responsibility that companies should take for decisions, processes and products. This is a reference to the consequences of actions taken in the past (e.g. if the investments made a few years earlier did 
UNDERSTANDING SUSTAINABLE BUSINESS MODELS

Agata Rudnicka not have negative effects on contemporary society and environment, what can be done to minimize them), present (and their consequences in the future, if the product may affect human health in the future a company will not sell it) and future projects (e.g. how the new planned investment will influence on the environment). Sustainability is about long thinking perspective what is the biggest challenge for business and current profit expectation. Meanwhile the longer time horizon is a crucial factor of sustainability risk management and generation of multiply values.

Next criterion is strictly related to the offered products. It is not possible to have sustainable products if the company limits its consciousness only to decisions that are made on one specific phase of life cycle of the product like e.g during the production process. In practice companies should monitor all phases of their products from the resource extraction to end-of-use phase [1]. Life cycle approach and Life cycle assessment (Kloepffer, 2008) are not new concepts and went under some modifications and adjustment to sustainability concept (Ny et al., 2006). It is known as one method of assessing environmental and social impacts of offered products and treated rather as an excellence tool than everyday practice. It is essential to understand the role of the whole supply chain network and relationships in value chain for sustainable business models. This give the opportunity to make more conscious decisions (like e.g. who should be the supplier, what can be done to minimize the negative environmental effect of our supply chain, how to organize the transportation process etc.) and plan operations which support sustainable development. More and more organizations see the limitation of their possible effects on the non-economic aspect of the business. This restriction is on the one hand the client, who does not necessarily take care about achieving the same goals as the company and on the other suppliers. The longer the supply chain, the greater the number of partners with potentially diverging aims and expectations which can significantly reduce the capacity to fulfill rules of conduct and cause additional problems. It is the reason why, it seems reasonable to create such business models, in which the flow of knowledge and information throughout the supply chain is conducive to build trust and makes it easier to enforce certain standards of behavior (Eriksson and Swensson, 2015; Abbasi and Nilsson, 2012; Andersen and Skjoett-Larsen, 2009).

This aspect is strictly linked to the time perspective. A significant number of organizations expects its business will be profitable in the short time perspective. On the other hand, there are organizations that invest in sustainability as a goal for bringing long-term business results (Ikea, Unilever, Marks and Spencer etc.). The discussion about profit maximization in business is indisputable. However profit as only positive financial result is insufficient. In the era of responsibility companies are obliged to conduct deeper analysis of cost and benefits which goes beyond single organization and includes various stakeholder groups. Cost- 
benefit analysis for sustainability supports the strategic decisions. The costs and benefits of social and environmental issues should be part of the evaluation of the profitability of each project, new product and decision. This kind of analysis may also include: carbon footprint, ecological footprint or social return on investment.

The last criterion is change. Based of literature review and business observation it could be assumed that the change and its durability is essential for sustainability. On the picture the idea of sustainable business model is presented in terms of change issue.

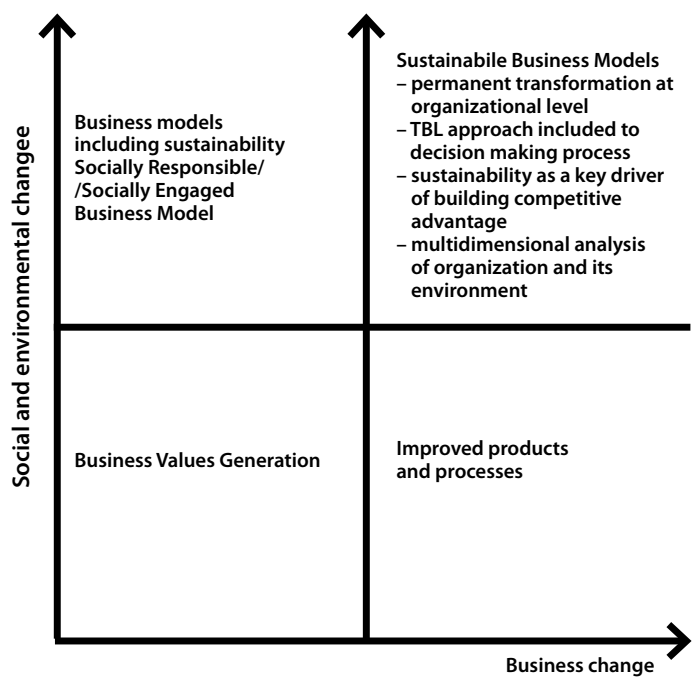

Figure 1.

Sustainable business model as business and society transformation

Source: Own elaboration.

Sustainable business model should be designed to enable social change and transform business itself. In contrast to social responsibility, which can results in the form of social change (e.g. funded scholarships benefits in the future resulting in finding a good job and prevent social exclusion) sustainable business models are seeking for solutions beneficial to the organization and its value chain including customers and society (e.g. a reduction of carbon footprint supply chain by offering more eco-friendly products resulting in better air quality, decreasing natural resources depletion etc.). In this approach organizations by SBM improve the quality of society and environment and at the same time are bringing economic profits.

\section{Conclusions}

The proposition of criteria for sustainable business models aims at making the minimum frameworks for designing and improving social and environmental dimension of business. It is a response to the existing in literature definitions 
UNDERSTANDING SUSTAINABLE BUSINESS MODELS

Agata Rudnicka and models of sustainability in business context. The criteria draw attention on sustainable business models as system concept which gives opportunity to satisfy present and future needs of all market participants. Taking into account the criteria and the awareness of change that must occur both at the level of the organization and its products the paper gives general outlines how to analyze if process of transformation is possible and how the current state looks like. The proposition is not about specific topics like: climate change, pollution or waste management that usually appear in the discussion about sustainability. Sustainable Business Models must be improved and adjusted to the changing environment to act the primary function which is earning money and creating added value.

\section{Notes}

[1] A similar point of view is adopted in the interpretation of the standard ISO 14001 about environmental management, where organizations are encouraged to analyze the environmental aspects taking into account the whole life cycle of products.

\section{References}

Abbasi, M., Nilsson, F. (2012), "Themes and challenges in making supply chains environmentally sustainable", Supply Chain Management: An International Journal, Vol. 17 No. 5, pp. 517-530. DOI: http://dx.doi.org/10.1108/13598541211258582

Andersen, M., Skjoett-Larsen, T. (2009), "Corporate social responsibility in global supply chains”, Supply Chain Management: An International Journal, Vol. 14 No. 2, pp. 75-86. DOI: http://dx.doi.org/10.1108/13598540910941948

Asif, M., Searcy, C., Zutshi, A., Ahmad, N. (2011), "An integrated management systems approach to corporate sustainability", European Business Review, Vol. 23 No. 4, pp. 353-367. DOI: http://dx.doi.org/10.1108/09555341111145744

Atiq, M., Mine Karatas-Ozkan, M. (2013), "Sustainable corporate entrepreneurship from a strategic corporate social responsibility perspective Current research and future opportunities", Entrepreneurship and Innovation, Vol. 14 No. 1, pp 5-14. DOI: http:// dx.doi.org/10.5367/ijei.2013.0102

Azzone, G., Bertele, U. (1994), "Exploiting green strategies for competitive advantage", Long Range Planning, Vol. 27 No. 6, pp. 69-81. DOI: http://dx.doi.org/10.1016/00 24-6301(94)90165-1

Bocken, N. M. P., Short, S. W., Rana, P., Evans, S. (2014), "A literature and practice review to develop sustainable business model archetypes", Journal of Cleaner Production, Vol. 65, pp. 42-56. DOI: http://dx.doi.org/10.1016/j.jclepro.2013.11.039

Chouinard, Y., Ellison, J., Ridgeway, R. (2011), “The Sustainable Economy”, Harvard Business Review, Vol. 10, pp. 52-62.

Cohen, B., Winn, M. I. (2007), "Market imperfections, opportunity and sustainable entrepreneurship", Journal of Business Venturing, Vol. 22, pp. 29-49. DOI: http://dx.doi. org/10.1016/j.jbusvent.2004.12.001

Dean, T. J., McMullen, J. S. (2007), “Toward a theory of sustainable entrepreneurship: reducing environmental degradation through entrepreneurial action", Journal of 
Business Venturing, Vol. 22 No. 1, pp. 50-76. DOI: http://dx.doi.org/10.1016/j. jbusvent.2005.09.003

Elkington, J. (1997), Cannibals with Forks: The Triple Bottom Line of $21^{\text {st }}$ Century Business, Capstone, Oxford.

UNDERSTANDING SUSTAINABLE BUSINESS MODELS

Agata Rudnicka

Epstein, M. J., Buhovac, A. R. (2010), "Solving the sustainability implementation challenge”, Organisational Dynamics, Vol. 39 No. 4, pp. 306-315. DOI: http://dx.doi. org/10.1016/j.orgdyn.2010.07.003

Eriksson, D., Svensson, G. (2015), "Elements affecting social responsibility in supply chains", Supply Chain Management: An International Journal, Vol. 20 No. 5, pp. 561-566. DOI: http://dx.doi.org/10.1108/SCM-06-2015-0203

Gauthier, J. (2017), "Sustainable business strategies: typologies and future directions", Society and Business Review, Vol. 12 No. 1, pp. 77-93. DOI: http://dx.doi. org/10.1108/SBR-01-2016-0005

Jonker, J. (2012), New Business Models, An exploratory study of changing transactions creating mutiple value(s), Working Paper, Nijmegen School of Management, Radboud University Nijmegen, The Netherlands.

Kloepffer, W. (2008), "Life cycle sustainability assessment of products", The International Journal of Life Cycle Assessment, Vol. 13 No. 2, pp. 13-89. DOI: http://dx.doi. org/10.1065/lca2008.02.376

Linton, J. D., Klassen, R., Jayaraman, V. (2007), "Sustainable supply chains: an introduction", Journal of Operations Management, Vol. 25 No. 6, pp. 1075-1082. DOI: http:// dx.doi.org/10.1016/j.jom.2007.01.012

Lozano, R. (2012), “Towards better embedding sustainability into companies' systems: an analysis of voluntary corporate initiatives", Journal of Cleaner Production, Vol. 25, pp 14-26. DOI: http://dx.doi.org/10.1016/j.jclepro.2011.11.060

Lubin, D. A., Esty, D. C. (2010), "The sustainability imperative", Harvard Business Review, Vol. 88 No. 5, pp. 42-50.

Lüdeke-Freund, F. (2009), "Business Model Concepts in Corporate Sustainability Contexts. From Rhetoric to a Generic Template for "Business Models for Sustainability", Center for Sustainability Management (CSM), Lüneburg: Leuphana Universität, Lüneburg.

Lüdeke-Freund, F. (2010), “Towards a conceptual framework of business models for sustainability", Knowledge Collaboration \& Learning for Sustainable Innovation ERSCP-EMSU conference, Delft, The Netherland, October 25-29, pp.1-28.

Magretta, J. (2002), "Why Business Models Matter", Harvard Business Review, Vol. 80 No. 5, pp. 86-92.

Miles, M. P., Munilla, L. S., Darroch, J. (2009), "Sustainable corporate entrepreneurship", International Entrepreneurship Management Journal, Vol. 5 No. 1, pp. 65-76. DOI: http://dx.doi.org/10.1007/s11365-008-0074-3

Model Behavior, 20 Business Model Innovations for Sustainability, available at: http:// www.sustainability.com (accessed 12 February 2017).

Nidumolu, R., Prahalad, C., Rangaswami, M. (2009), "Why sustainability is now the key driver of innovation", Harvard Business Review, Vol. 87 No. 9, pp. 56-64.

Ny, H., MacDonald, J. P., Broman, G., Yamamoto, R., Henrik, R. K-H. (2006), "Sustainability Constraints as System Boundaries: An Approach to Making Life-Cycle 
UNDERSTANDING SUSTAINABLE BUSINESS MODELS

Agata Rudnicka
Management Strategic”, Journal of Industrial Ecology, Vol. 10 No. 1-2, pp. 61-77. DOI: http://dx.doi.org/10.1162/108819806775545349

Osterwalder, A. (2004), "The Business Model Ontology a proposition in a design science approach", These, University of Lausanne, Ecole des Hautes Etudes Commerciales HEC, p. 173.

Osterwalder, A., Pigneur, Y., Tucci, C. L. (2005), "Clarifying Business Models: Origins, Present, and Future of the Concept", Communications of the Association for Information Systems, Vol. 16, pp. 1-25.

Pacheco, D. F., Dean, T. J., Payne, D. S. (2010), "Escaping the green prison: entrepreneurship and the creation of opportunities for sustainable development", Journal of Business Venturing, Vol. 25 No. 5, pp. 464-480. DOI: http://dx.doi.org/10.1016/j. jbusvent.2009.07.006

Ross, A., Parker, H., Benavides, M. (2012), "Sustainability and supply chain infrastructure development", Management Decision, Vol. 50 No. 10, pp. 1891-1910. DOI: http:// dx.doi.org/10.1108/00251741211279666

Salzmann, O., Ionescu-Somers, A., Steger, U. (2005), "The business case for corporate sustainability: literature review and research options", European Management Journal, Vol. 23 No. 1, pp. 27-36. DOI: http://dx.doi.org/10.1016/j.emj.2004.12.007

Seuring, S., Müller, M. (2008), "From a literature review to a conceptual framework for sustainable supply chain management", Journal of Cleaner Production, Vol. 16 No. 15, pp. 1699-1710. DOI: http://dx.doi.org/10.1016/j.jclepro.2008.04.020

Stubbs, W., Cocklin, Ch. (2008), "Conceptualizing a 'Sustainability Business Model'”, Organization \& Environment, Vol. 21 No. 2, pp. 103-127. DOI: http://dx.doi. org/10.1177/1086026608318042

Weber, M. (2008), "The business case for corporate social responsibility: A company-level measurement approach for CSR”, European Management Journal, Vol. 26 No. 4, pp. 247-261. DOI: http://dx.doi.org/10.1016/j.emj.2008.01.006 